\title{
Mengatasi Gerakan Separatis Melalui Operasi \\ Militer Selain Perang (OMSP) \\ (Tinjauan Hukum Humaniter Dan Hukum Nasional)
}

\author{
Yuniarti Dwi Pratiwi ${ }^{1}$
}

\begin{abstract}
Abstrak: Negara Kesatuan Republik Indonesia (NKRI) merupakan negara yang terbentuk dari keberagaman budaya dan bahasa yang tersebar dari Sabang hingga Merauke yang dikenal dengan "Bhinneka Tunggal Ika". Namun, tidak sedikit segelintir atau sekelompok golongan masyarakat yang berupaya merongrong kesatuan dan kedaulatan Bangsa ini. Gerakan separatisme merupakan suatu gerakan yang bertujuan untuk mendapatkan kedaulatan dan memisahkan suatu wilayah atau kelompok manusia dari satu sama lain. Gerakan ini muncul dikarenakan ketidakpuasan masyarakat atau segelintir orangterhadap pemerintah pusat maupun pemerintah daerah dalam memberikan rasa keadilan.Operasi Militer Selain Perang (OMSP) merupakan sebuah keharusan yang dilakukan oleh setiap Negara guna menanggulangi gerakangerakan separatisme.Namun tidak sedikit pula OMSP yang dilakukan oleh pihak militer selalu menimbulkan sebuah polemik dan amino di tengah-tengah masyarakat yaitu berupa pelanggaran HAM. Atas dasar inilah, tulisan ini bermaksud untuk mengupas persoalan tugas OMSP di Indonesia yang akan ditinjau berdasarkan konsep Hukum Humaniter Internasional dan Hukum Nasional.
\end{abstract}

Kata Kunci: Separatisme, OMSP, Ham, Hukum Humaniter, Hukum nasional. 


\section{PENDAHULUAN}

Dalam kehidupan politik negara dan bangsa, gerakan separatis yang ditempuh oleh kelompok kepentingan dapat menjadi ancaman yang cukup serius terhadap stabilitas nasional dan keutuhan NKRI.Gerakan separatis bukan sesuatu yang tidak mungkin menjadi musuh dan ancaman non-militer negara (nonmilitary/non-traditional security threat) bilamana pemerintah sebagai pemegang mandat penyelenggaraan administrasi negara tidak mampu mengelola dan mendistribusikan kewenangannya dengan tepat.

Istilah Separatis atau separatisme itu sendiri ditujukan pada tindakan seseorang atau sekelompok orang atau komunitas yang berada dalam satu kesatuan besar yang hendak memisahkan diri atau keluar dari komunitas atau kesatuan besar, denganmaksud berdiri sendiri sebagai negara atau bangsa yang merdeka.Tujuan memisahkan diri untuk menjadi negara merdeka lepas dari negara induknya dalam berbagai literatur Hukum Internasional pada hakekatnya hanya merupakan salah satu tujuan dari pemberontakan yang terjadi di suatu negara. Adapun tujuan pemberontakan yang lain adalah untuk menggulingkan pemerintah yang sah dan menggantikannya dengan pemerintah baru sesuai dengan kaum separatis, ataupun untuk bergabung dengan negara lain (integration), atau kemungkinan yang lain adalah untuk menuntut otonomi yang lebih luas.

Apapun maksud dan tujuan kaum separatis, merupakan perbuatan melanggar hukum nasional negara tempat terjadinya pemberontakan tersebut.Hal ini dikarenakan perbuatan para separatis merupakan pemaksaan kehendak kepada pemerintah yang sah dalam rangka mencapai tujuan yang diyakininya.Di atas semuanya itu, tuntutan untuk memisahkan diri dari negara induknya tentu merupakan ancaman terhadap integritas suatu negara.

Konsepsi mencegah berkembangnya separatisme dalam masyarakat Indonesia pada hakikatnya adalah dengan mewaspadai secara terus-menerus fenomena sosial, utamanya radikalisme

${ }^{1}$ Penulis adalah pemerhati pertahanan di Lembaga Kajian Pertahanan untuk Kedaulatan NKRI "KERIS". Penulis dapat dihubungi melalui email yuniartiibbas@gmail.com yang mampu mengancam eksistensi NKRI.Bentuk pencegahan dan penanggulangan separatisme di Indonesia, dilakukan melalui Operasi Militer Selain Perang (OMSP) yang diatur dalam Undang-Undang Nomor 34 Tahun 2004 tentang Tentara Nasional Indonesia. Dalam Pasal 7 ayat 2 dijelaskan mengenai pemisahan tugas pokok TNI melalui Operasi Militer Untuk Perang (OMP) dan Operasi Militer Selain Perang (OMSP), serta pelaksanaan operasi militer selain perang yang harus berdasarkan kebijakan dan keputusan politik negara. Operasi Militer Selain Perang (OMSP) merupakan sebuah keniscayaan di sebuah negara, karena meskipun tidak ada perang, masih ada fungsi lain yakni detterent dan bargaining.

Namun, dalam penanggulangan separatisme melalui OMSP tidak jarang muncul isu-isu pelanggaran HAM. Oleh karena itu perlu mengkaji secara hukum/yuridis menurut Hukum Internasional yang berlaku yakni Hukum Humaniter Internasional yang kemudian diimplementasikan kedalam Hukum Nasional, meskipun penulis dirasakan kurang memiliki kemampuan dalam hal penulisan hukum.

\section{METODE PENELITIAN}

Metode yang digunakan untuk menganalisis permasalahan ini adalah yuridis normatif dengan meneliti bahan pustaka atau data sekunder baik berupa bahan hukum primer, sekunder maupun tersier. Data yang diperoleh akan dianalisis secara kualitatif yakni semua data yang berhasil dikumpulkan akan diteliti dan dipelajari secara utuh, selanjutnya data tersebut akan diuraikan dalam bentuk penyajian deskriptif analisis yaitu penjabaran dan penggambaran hal-hal yang berkaitan dengan permasalahan.

\subsection{Dasar Hukum Humaniter Internasional (HHI)}

Hukum perang atau yang sering disebut dengan Hukum Humaniter internasional, atau hukum sengketa bersenjata memiliki sejarah yang sama tuanya dengan peradaban manusia, atau sama tuanya dengan perang itu sendiri. Hukum Humaniter Internasional menjaga serangkaian hak asasi manusia yang tidak 
dapat dilanggar sekalipun dalam situasi konflik bersenjata. Dalam Hukum Humaniter Internasional sendiri terdapat dua tujuan utama yaitu:

a. Melindungi orang pada saat perang atau tidak sedang berpartisipasi dalam kekerasan;

b. Membatasi cara dan metode berperang. ${ }^{2}$

Sedangkan dari berbagai kepustakaan tujuan Hukum Humaniter Internasional adalah:

1. Memberikan perlindungan terhadap kombatan maupun penduduk sipil dari penderitaan yang tidak perlu (unnecessary suffering);

2. Menjamin hak asasi manusia yang sangat fundamental bagi mereka yang jatuh ke tangan musuh. Kombatan yang jatuh ke tangan musuh harus dilindungi dan dirawat serta berhak diperlakukan sebagai tawanan perang;

3. Mencegah dilakukannya perang secara kejam tanpa mengenal batas. Di sini, yang terpenting adalah asas perikemanusiaan. $^{3}$

Secara substansi Hukum Humaniter Internasional dapat dibedakan menjadi dua kelompok utama yang saling berkaitan, yakni Hukum Den Haag (the Law of the Hague) dan kelompok Hukum Jenewa ( The Law of Geneva).Secara substantif, Hukum Den Haag lebih banyak berisi norma tentang perilaku dalam perang dan sarana serta cara yang diperbolehkan dalam perang (conduct of war and permissible means and methods of war). Sedangkan, Hukum Jenewa lebih banyak mengatur perlindungan terhadap korban perang (tawanan perang maupun warga sipil) yang berada dalam penguasaan musuh (protection of war victims in enemy hands). Dengan kata lain, kedua hukum

\footnotetext{
${ }^{2}$ Hukum Pidana Internasional dan Perempuan, Buku I, Sebuah Acuan Untuk Praktisi, Publikasi Komnas Perempuan, Hal.6

${ }^{3}$ Frederic de Mullinen, Handbook on the Law of the War for Armed Forces, ICRC, Geneva, 1987, hlm. 2., yang menyatakan bahwa : "Hukum Perang bertujuan untuk membatasi dan menghapuskan sejauh mungkin kekejaman perang. Oleh karena itu diperlukan suatu hukum yang dapat menyeimbangkan antara kepentingan militer dan kemanusiaan".
}

inilah yang menjadi sumber utama dari hukum humaniter.

A. Hukum Den Haag(The Hague Laws) memiliki fokus pengaturan terhadap tata cara peperangan serta jenis persenjataan yang diperkenankan untuk dipakai selama masa perang. Pembahasan mengenai hukum ini, berorientasi kepada Konferensi Perdamaian I pada tahun 1899 dan Konferensi Perdamaian II pada tahun 1907. Rangkaian konvensi inilah yang pada akhirnya dikenal dengan sebutan "Hukum den Haag". Ada 2 prinsip penting yang terdapat dalam hukum ini yaitu :

1. Prinsip "The right of belligerents to adopt means of injuring the enemy is not unlimited"yang berarti adalah berarti ada tata cara tertentu serta alat-alat tertentu yang dilarang untuk digunakan selama masa perang.

2. Prinsip yang dikenal dengan "Martens Clause", yang dapat ditemukan dalam Pembukaan Konvensi Den Haag. Klausula Marten ini merupakan suatu klausula yang memberi ketentuan apabila Hukum Humaniter belum memberi suatu aturan terhadap halhal tertentu, maka ketentuan yang dapat dipergunakan adalah ketentuan yang harus mengacu dan berpedoman kepada prinsip-prinsip Hukum Internasional yang dibentuk dari kebiasaan yang ada di antara negara-negara, hukum kemanusiaan serta yang berasal dari hati nurani masyarakat. ${ }^{4}$

B. Instrumen lainnya dari Hukum Humaniter Internasional adalah keempat Konvensi Jenewa Tahun 1949 yang berupa :

1. Konvensi Jenewa 1949 tentang Perbaikan Keadaan Anggota Angkatan Perang yang Luka dan Sakit di Medan Pertempuran Darat(Geneva Convention for the Amelioration of the Condition of the

\footnotetext{
${ }^{4}$ Hukum Pidana Internasional dan Perempuan, Buku I, Sebuah Acuan Untuk Praktisi, Publikasi Komnas Perempuan, Hal.17-18
}

Volume 3 Nomor 1, Desember 2017 | 20 
Wounded and Sick in Armed Forces in the Field);

2. Konvensi Jenewa 1949 tentang Perbaikan Keadaan Anggota Angkatan Perang di Laut yang Luka, Sakit dan Korban Karam(Geneva Convention for the Amelioration of the condition of the Wounded, Sick and Shipwrecked Members of Armed Froces at Sea);

3. Konvensi Jenewa 1949 tentang Perlakuan Tawanan

Perang(Geneva Convention relatiive to the Treatment of Prisoners of War);

4. Konvensi Jenewa 1949 tentang Perlindungan Orang-orang Sipil di Waktu Perang(Geneva Convention relative to the Treatment of Prisoners of War). ${ }^{5}$

Disamping itu Konvensi Jenewa juga melahirkan dua Protokol yang disusun Tahun 1977 yakni:

1. Protokol I, berisikan beberapa aturan mengenai perang atau konflik bersenjata yang bersifat lintas negara (internasional);

2. Protokol II, berisikan beberapa aturan mengenai perang atau konflik bersenjata yang terjadi di wilayah salah satu pihak peserta agung antara pasukannya dengan pemberontak yang ada di wilayah tersebut. Dengan kata lain, sifat nya non-internasional

Empat Prinsip Dasar Hukum Perang

1. Kekerasan hanya digunakan sejauh diperlukan untuk mencapai tujuan militer yang sah (Principles of Military Neccersity atau Prinsip Keperluan Militer);

2. Semua tindakan yang diambil harus sesuai dengan prinsip-prinsip kemanusiaan (Principles of Humanity, seperti yang tersebut dalam Klausula Martens);

3. Serangan hanya boleh dilancarkan terhadap sasaran militer, dan dengan cara yang meminimalkan kerugian pada penduduk sipil dan objek-objek sipil. Serangan sama sekali tidak boleh

\footnotetext{
${ }^{5}$ Hukum Pidana Internasional, Arie Siswanto, Andi
}

Yogyakarta, 2015, Hal. 159 dengan sengaja diarahkan kepada penduduk sipil dan obek sipil (Principles of Distinction atau Prinsip Pembedaan);

4. Bilamana suatu serangan mungkin mengakibatkan korban sipil yang tidak disengaja, serangan tersebut hanya dapat dilakukan apabila kerugian terhadap warga sipil dan objek sipil tidak terlalu banyak jika dibandingkan dengan keuntungan militer yang didapat (Principles of Proportionality atau Prinsip Proposionalitas).

Prinsip-prinsip ini menghasilkan beberapa ketentuan dasar yang tidak boleh dilanggar dalam konflik bersenjata :

1. Hors de combat (maksudnya adalah tentara yang telah meletakkan senjata karena terluka atau ditahan) dan masyarakat sipil yang tidak terlibat konflik wajib dilindungi dan dihormati, khususnya kehidupan serta integritas moral dan fisikmereka. Tanpa terkecuali mereka patut dilindungi dan diperlakukan secara manusiawi tanpa pembedaan yang merugikan;

2. Tidak diperbolehkan untuk membunuh atau melukai musuh yang telah menyerah atau hors de combat;

3. Mereka yang sakit atau terluka harus dievakuasi dan diberi perawatan oleh pihak yang berkonflik. Perlindungan harus diberikan pada pekerja medis, serta tempat pelayanan, transportasi serta peralatan yang digunakannya. Tanda palang merah atau bulan sabit merah adalah symbol yang menandakan perlindungan ini, dan harus dihormati;

4. Kombatan dan masyarakat sipil yang tertangkap oleh pihak musuh harus dilindungi kehidupannya, martabat, hak-hak pribadi dan kepercayaannya. Mereka dilindungi dari semua aksi kekerasan dan balas dendam. Mereka mempunyai hak untuk korespondensi dengan keluarga dan untuk menerima bantuan;

5. Semua orang punya hak untuk mendapatkan hak-hak dasar dalam proses peradilan. Tidak seorang pun boleh dijadikan bertanggung jawab atas tindakan yang dilakukannya. Tidak seorangpun boleh mengalami

Volume 3 Nomor 1, Desember 2017 | 21 
penyiksaan fisik dan mental, dan hukuman pemukulan atau perlakuan kejam atau merendahkan.

6. Pihak yang berkonflik dan anggota angkatan bersenjata tidak mempunyai pilihan metode dan alat perang tanpa batasan. Tidak diperbolehkan menggunakan senjata atau metode perang yang mengakibatkan kerugian dan penderitaan yang berlebihan;

7. Pihak yang berkonflik harus membedakan masyakarat sipil dan kombatan untuk melindungi masyarakat sipil dan harta bendanya. Masyarakat sipil, atau perorangan, tidak boleh menjadi sasaran penyerangan. Serangan hanya boleh dilakukan pada target militer. ${ }^{6}$

Hukum Humaniter Internasional ini berlaku ketika terjadi (i) konflik bersenjata lintas batas; (ii) konflik bersenjata noninternasional seperti perang sipil, yakni konflik yang terjadi dalam batas wilayah Negara.Secara konsisten, subtansi dan tujuan utama dari Hukum Humaniter Internasional, yakni memanusiawikan perang atau konflik bersenjata. ${ }^{7}$

\subsection{Konflik Bersenjata Internasional vs Non Internasional}

Dalam hal ini Hukum Humaniter Internasional berlaku untuk konflik bersenjata internasional maupun internal (non internasional).

a. Konflik Bersenjata Internasional Konflik bersenjata Internasional terjadi di mana sebuah Negara menggunakan kekuatan bersenjata terhgadap Negara lain, melalui angkatan bersenjatanya sendiri atau kelompok lain. Hukum Humaniter Internasional diterapkan pada situasi pendudukan sebagian atau seluruh daerah;

b. Konflik Bersenjata Internal/ NonInternasional

Sedangkan konflik bersenjata internal terjadi pada saat konfrontasi bersenjata mengambil tempat di batas Negara atau melibatkan konfrontasi

\footnotetext{
${ }^{6}$ Hukum Pidana Internasional dan Perempuan, Buku I, Sebuah Acuan Untuk Praktisi, Publikasi Komnas Perempuan, Hal.21

${ }^{7}$ lbid, Hal. 6
}

antara penguasa suatu Negara dan kelompok bersenjata atau antara kelompok bersenjata. ciri-ciri :

Definisi pihak bertikai pun mempunyai

a. Dipimpin oleh seorang komandan yang bertanggung jawab atas anak buahnya;

b. Anggotanya memegang senjata secara terbuka;

c. Memakai emblem atau seragam tertentu;

d. Melakukan operasi sesuai dengan hukum dan kebiasaan perang.

Dalam Pasal 1 ayat 2 Protokol Tambahan II Tahun 1977, disebutkan bahwa situasi dan ketegnagan di dalam negeri, seperti situasi kerusuhan yang terisolasi dan tindakan kekerasan sporadis atau tindakan sejenis lainnya bukanlah merupakan konflik bersenjata noninternasional. $^{8}$

\subsection{SEPARATISME MENURUT HUKUM HUMANITER INTERNASIONAL}

Kata separatisme berasal dari bahasa Inggris yaitu "separate", yang dalam kata kerja transitip berarti "memisahkan" dan dalam kata kerja intransitip berarti "berpisah", sedangkan dalam arti orang yang meisahkan diri disebut dengat istilah "separatist".

Pada umumnya, para separatist melakukan tindakan-tindakan yang bertujuan melepaskan suatu daerah atau wilayah dari satu Negara yang merdeka dan berdaulat, melalui dengan berbagai macam cara, daya, dan upaya guna mencapai tujuan utama mereka yakni pemisahan daerah atau wilayah tertentu dimaksud agar lepas dari Negara induknya, atau biasa dikenal dengan istilah separatism. $^{9}$

Gerakan separatisme muncul disebabkan beberapa faktor antara lain :

1. Latar belakang sejarah;

2. Perbedaan etnik, suku, budaya dan kultur;

\footnotetext{
${ }^{8}$ lbid. Hal 9

${ }^{9}$ Gerakan Separatisme ditinjau dari Hukum Humaniter Internasional, Abdul Hamid, Fakultas Hukum Universitas Sumatera Utara, 2001, Hal.8
}

Volume 3 Nomor 1, Desember 2017 | 22 
3. Perbedaan keyakinan atau agama;

4. Perbedaan social dan ekonomi;

5. Diskriminasi politik dari pemerintah yang sah;

6. Letak geografis. ${ }^{10}$

Sebagaimana telah dijelaskan diatas, dalam pertikaian bersenjata yang bersifat non-internasional diatur dalam Pasal 3 common articles Konvensi Jenewa 1949 dan Protokol Tambahan II Tahun 1977. Dalam Pasal 3 Konvensi Jenewa 1949 memang tidak dijelaskan secara rinci mengenai definisi dari "pertikaian bersenjata yang tidak bersifat internasional". Pasal 3 ini hanya menyebutkan bahwa :

"In the case of armed conflict not an international character occurring in the territory of one of the High Contracting Parties, each Party to a conflict shall be bound to apply, as minimum, the following provisions..."11

Dengan kata lain, pemberontakan atau perang saudara yang terjadi di dalam wilayah suatu Negara Pihak Konvensi dapatlah dikatakan sebagai pertikaian bersenjata yang tidak bersifat internasional.

Sebaliknya, Protokol Tambahan II Tahun 1977 pada Pasal 1, memberikan kriteria-kriteria yang lebih jelas mengenai peristiwa pertikaian bersenjata noninternasional. Kriteria tersebut adalah :

1. Pertikaian terjadi di dalam wilayah Pihak Peserta Agung;

2. Pertikaian terjadi antara angkatan bersenjata Pihak Peserta Agung dengan kekuatan bersenjata pihak yang memberontak (dissident);

3. Kekuatan bersenjata pihak pemberontak ini harus berada di bawah suatu komando yang bertanggung jawab;

4. Pihak pemberontak telah menguasai sebagian wilayah Negara, dan;

5. Pihak pemberontak dapat melaksanakan ketentuan Protokol Tambahan II Tahun 1977.

Kriteria-kriteria tersebut tidak bersifat fakultatif. Dengan kata lain,kriteria-kriteria tersebut harus dipenuhi secara keseluruhan dan bersamaan agar suatu peristiwa dapat dikatakan sebagai suatu pertikaian bersenjata non-internasional. Apabila peristiwa didalam negeri tersebut hanya berupa internal tensions (ketegangan dalam negeri) maka Protokol Tambahan II Tahun 1977 tidak berlaku, melainkan Hukum Nasional negara tersebut yang berlaku. ${ }^{12}$

Suatu peristiwa dikategorikan sebagai ketegangan dalam negeri, apabila terjadi salah satu atau lebih dari keadaankeadaan di bawah ini, yaitu :

1. Terjadi banyak penahanan secara massal;

2. Banyak tahanan politik;

3. Adanya penyiksaan atau kondisi yang tidak manusiawi dalam tahanan;

4. Penerapan keadaan darurat oleh pemerintah;

5. Meningkatnya jumlah orang-orang hilang. ${ }^{13}$

Kondisi ketegangan dalam negeriini dapat berubah menjadi kondisi pertikaian bersenjata non-internasional apabila pihak lawan dari pemerintah yang sedang berkuasa mulai terorganisir dan intensitas ketegangannya meningkat cukup tinggi.

Dalam hal ini, kasus-kasus separatisme yang terjadi di Indonesia sejauh ini tidak dapat dikatakan hanyalah merupakan internal tensions semata, karena intensitas penahanan massal, perlakuan tidak manusiawi, pertikaian bersenjata secara terbuka dan orang-orang hilang cukup tinggi. Disamping itu apabila kita mendasarkan diri pada Pasal 3 common articles Konvensi Jenewa 1949, maka selama suatu peristiwa bukanlah merupakan tindakan penggarongan atau huru-hara yang bersifat sporadis, maka separatisme dapat dikategorikan sebagai pertikaian bersenjata yang tidak bersifat internasional.

Oleh karena itu, Hukum Humaniter Internasional, khususnya Pasal 3 common articles Konvensi-konvensi Jenewa 1949 haruslah ditetapkan.Pasal 3 ini menyebutkan bahwa apabila terjadi pertikaian bersenjata yang tidak bersifat

\footnotetext{
12 Ibid, Hal 43

13 Ibid. Hal 43-45
}

Volume 3 Nomor 1, Desember 2017 | 23 
internasional maka Negara Pihak Konvensi dilarang melakukan tindakan kekerasan terhadap jiwa dan raga, seperti penganiayaan.Penyanderaan

pembunuhan, pemerkosaan, dan penjatuhan hukuman tanpa adanya pengadilan.

\subsection{DASAR HUKUM BERLAKUNYA OMSP DI INDONESIA}

$\mathrm{Di}$ Indonesia, istilah OMSP secara resmi baru dikenal pada tahun 2002 seiring dengan disahkannya Undang-Undang Pertahanan. Meski demikian, konsep tugas perbantuan sudah dikenal jauh sebelum itu. Di era Soekarno, pengaturan mengenai tugas perbantuan pada masa damai diatur dalam Peraturan Pemerintah Nomor 63 Tahun 1954 tentang Permintaan dan Pelaksanaan Bantuan Militer sebagai pengganti dari Keputusan Presiden RI Nomor 175 dan Nomor 213 Tahun 1952. Sementara keterlibatan militer dalam keadaan darurat, baru muncul pada tahun 1959 dan diatur dalam Peraturan Pemerintah Pengganti Undang-Undang Nomor 23 Tahun 1959 tentang Keadaan Bahaya sebagai pengganti UndangUndang Nomor 74 Tahun 1957 (Lembaran Negara No.160 Tahun 1957) dan Penetapan Keadaan Bahaya. ${ }^{14}$

Menyesuaikan dengan Perppu Keadaan Bahaya, peraturan tugas perbantuan (dalam masa damai) kembali disempurnakan melalui Peraturan Pemerintah Nomor 16 Tahun 1960.Dalam perkembangan selanjutnya di era Presiden Soeharto, diskursus mengenai tugas perbantuan menjadi tidak signifikan. Hal ini disebabkan oleh sistem pemerintahan otoriter Soeharto dan doktirn dwi-fungsi ABRI yang melegitimasi militer untuk terlibat secara dominan pada ranah-ranah sipil khususnya keterlibatan dalam peran sosial dan politik.Dengan jatuhnya rezim Soeharto dan Indonesia menganut sistem pemerintahan demokrasi, kebijakan dwifungsi dihapuskan dan agenda Reformasi Sektor Keamanan (RSK) mulai dilaksanakan. ${ }^{15}$

\footnotetext{
14 Jurnal Keamanan Nasional, Pusat Kajian Keamanan Nasional, Universitas Bhayangkara Jakarta Raya, Diandra Megaputri Mengko, Volume I No. 2015, Hal. 181

15 Ibid 180
}

Pada era reformasi, istilah tugas perbantuan pertama kali muncul pada Pasal 4 TAP MPR No.VII/2000 tentang Peran Tentara Nasional Indonesia dan Kepolisian Republik Indoneesia yang menjelaskan:

1. TNI membantu penyelenggaraan kegiatan kemanusiaan (civic mission);

2. TNI memberi bantuan kepada Polri dalam rangka tugas keamanan, atas permintaan yang diatur dalam UndangUndang;

3. TNI membantu secara aktif tugas pemeliharaan perdamaian dunia (peace keeping operation) di bawah bendera PBB. ${ }^{16}$

Selanjutnya, munculah istilah Operasi Militer Selain Perang (OMSP) pada Pasal 10 UU Pertahanan Nomor 3 Tahun 2002tentang Pertahanan, namun penjelasan terkait jenis-jenis OMSP baru muncul pada Pasal 7 Undang-Undang Nomor 34 Tahun 2004 tentang Tentara Nasional Indonesia. Penjelasan jenis-jenis OMSP pada Undang-Undang TNI juga mencakup jenis operasi tugas perbantuan yang sebelumnya ada pada TAP MPR, namun dijabarkan secara lebih luas. Jenis OMSP ini dibagi dalam 14 jenis operasi, yang meliputi :

1. Mengatasi gerakan separatisme bersenjata;

2. Mengatasi pemberontakan bersenjata;

3. Mengatasi aksi terorisme;

4. Mengamankan wilayah perbatasan;

5. Mengamankan objek vital nasional yang bersifat strategis;

6. Melaksanakan tugas perdamaian dunia sesuai dengan kebijakan politik luar negeri;

7. Mengamankan Presiden dan wakil presiden beserta keluarganya;

8. Memberdayakan wilayah pertahanan dan kekuatan pendukungnya secara dini sesuai dengan sistem pertahanan semesta;

9. Membantu tugas pemerintahan di daerah;

10. Membantu kepolisian Negara Republik Indonesia dalam rangka tugas

\footnotetext{
${ }^{16}$ TAP MPR No. VII.2000 tentang Peran Tentara Republik Indonesia dan Kepolisian Republik Indonesia
}

Volume 3 Nomor 1, Desember 2017 | 24 
keamanan dan ketertiban masyarakat yang diatur dalam undang-undang;

11. Membantu mengamankan tamu negara setingkat kepala dan perwakilan pemerintah asing yang sedang berada di Indonesia;

12. Membantu menanggulangi akibat bencana alam, pengungsian, dan pemberian bantuan kemanusiaan;

13. Membantu pencarian dan pertolongan dalam kecelakaan (search and rescue);

14. Membantu pemerintah dalam pengamanan pelayaran dan penerbangan terhadap pembajakan, perompakan, dan penyelundupan. ${ }^{17}$

Namun demikian, pelaksanaan OMSP tersebut hanya bisa dilakukan jika ada keputusan politik negara sebagaimana di tegaskan dalam Pasal 7 ayat 3 Undangundang TNI.Dalam Penjelasan Pasal 5 Undang-Undang Nomor 34 Tahun 2004 tentang Tentara Nasional Indonesia yang dimaksud Keputusan politik negara adalah kebijakan politik pemerintah bersama-sama dewan perwakilan rakyat (DPR) yang dirumuskan melalui mekanisme hubungan kerja antara pemerintah dengan DPR, seperti rapat konsultasi dan rapat kerja sesuai dengan peraturan perundangundangan.

Dalam Buku Putih pertahanan tahun 2008 juga di jelaskan bahwa pelaksanaan OMSP hanya dapat dilakukan apabila penanganan dengan cara-cara biasa atau penanganan fungsional sudah tidak efektif lagi atau diperkirakan akan menimbulkan korban yang besar, kerusakan infrastruktur dan properti yang parah. Namun sayangnya dimasa Reformasi ini belum ada regulasi tentang tugas perbantuan militer dalam kerangka OMSP yang spesifik dan komprehensif di Indonesia.

Justru pengaturan tentang tugas perbantuan TNI dalam kerangka OMSP diatur secara parsial dan sektoral di dalam beberapa aturan seperti diatur dalam Undang-Undang Nomor 7 Tahun 2012 tentang Penanganan Konflik Sosial, Undang-Undang Nomor 3 Tahun 2002 tentang Pertahanan, Inpres Penanganan

\footnotetext{
17 Undang-Undang Nomor 34 Tahun 2004 tentang Tentara Republik Indonesia
}

Gangguan Keamanan Dalam Negeri Nomor 2 Tahun 2013 dan Undang-Undang Nomor 9 Tahun 2003 tentang Terorisme. Bahkan, pengaturan tentang tugas perbantuan militer kepada pemerintah dalam hal ini kementerian dan instansi lainnya hanya di atur dalam bentuk memorandum of understanding antara Panglima TNI dengan kementerian serta instansi terkait. ${ }^{18}$

\subsection{MENGATASI SEPARATISME DI INDONESIA MELALUI OMSP}

Gerakan separatis masih menjadi isu keamanan dalam negeri, baik dalam bentuk gerakan separatis politik maupun gerakan separatis bersenjata.Masih terdapat pihak-pihak yang berkeinginan untuk memisahkan diri dari NKRI dengan mengeksploitasi kelemahan penyelenggaraan fungsi pemerintahan Indonesia menempatkan separatisme sebagai ancaman yang serius karena secara langsung mengancam keutuhan wilayah NKRI dan mengancam keselamatan bangsa.Akar masalah separatisme terletak pada distribusi hak.

Hak politik, ekonomi, dan distribusi keadilan yang tidak merata, yang menyebabkan kelompok tertentu merasa tidak nyaman untuk tinggal di dalam naungan NKRI. Selama akar masalah tersebut tidak dipecahkan, potensi separatisme akan selalu ada. Bangsa Indonesia menyadari dan memiliki komitmen bahwa berada dalam wadah NKRI merupakan putusan politik yang tepat dan final.Sesuai dengan amanat undangundang, pertahanan negara berfungsi untuk menjamin keutuhan wilayah NKRI. Namun, diakui usaha untuk mengatasi akar masalah separatisme belum dapat diwujudkan secara penuh antara lain akibat belum merata dan terpadunya pembangunan nasional. ${ }^{19}$

Adapun gerakan separatisme tentunya akan mengancam keutuhan NKRI, oleh karena itu dirasa penting keterlibatan TNI dalam penanggulangan separatisme, yaitu melalui Operasi Militer Selain Perang.

\footnotetext{
${ }^{18}$ Ibid. Hal 183

${ }^{19}$ Buku Putih Pertahanan Indonesia 2014, Departemen Pertahanan Republik Indonesia
}

Volume 3 Nomor 1, Desember 2017 | 25 
Pemberlakuan OMSP ini, sejalan dengan tujuan pertahanan negara, sebagaimana telah diuraikan dalam Pasal 4 dan Pasal 5 Undang-Undang Nomor 3 Tahun 2002 tentang Pertahanan Negara berbunyi:

"Pertahanan negara bertujuan untuk menjaga dan melindungi kedaulatan negara, keutuhan wilayah negara Kesatuan Republik Indonesia, dan keselamatan segenap bangsa dari segala bentuk ancaman".

\begin{abstract}
Penjelasan pasal 4 UndangUndang Nomor 3 Tahun 2002 tentang Pertahanan Negara, yakni: "Yang dimaksud dengan ancaman adalah setiap usaha dan kegiatan baik dari dalam negeri maupun luar negeri yang dinilai membahayakan kedaulatan negara, keutuhan wilayah negara, dan keselamatan segenap bangsa".
\end{abstract}

Pasal 5 berbunyi: "Pertahanan negara berfungsi untuk mewujudkan dan mempertahankan seluruh wilayah Negara Kesatuan Republik Indonesia sebagai satu kesatuan pertahanan". Penjelasan pasal 5 Undang-Undang Nomor 3 Tahun 2002 tentang Pertahanan Negara yakni : "Yang dimaksud dengan seluruh wilayah Negara Kesatuan Republik Indonesia sebagai satu kesatuan pertahanan adalah bahwa ancaman terhadap sebagian wilayah merupakan ancaman terhadap seluruh wilayah dan menjadi tanggung jawab segenap bangsa". 20

Adapun asas-asas yang dipergunakan Tentara Nasional Indonesia dalam rangka melaksanakan Operasi Militer Selain Perang adalah sebagai berikut :

a. Asas tujuan

Setiap penyelenggaraan operasi harus memiliki rumusan tujuan/sasaran yang jelas sehingga tidak menimbulkan

\footnotetext{
${ }^{20}$ Undang-Undang Nomor 3 Tahun 2002 tentang Pertahanan Negara
}

keraguan dalam pencapaian tugas pokok.

b. Asas kesatuan komando dan pengendalian Seluruh kegiatan operasi yang dilaksanakan dalam kerangka OMSP berada di bawah satu komando / penanggung jawab dari institusi Negara yang ditunjuk sesuai peraturan perundang-undangan yang berlaku.

c. Asas Proporsionalitas diartikan bahwa kekuatan, persenjataan dan peralatan TNI yang dikerahkan dalam pelaksanaan operasi dilakukan secara sepadan, tidak berlebihan, memiliki prosedur standar operasi yang jelas, terhindar dari tindakan diluar batas kewajaran.

d. Asas keamanan Tindakan yang tepat untuk menjamin keamanan, kerahasiaan, keleluasaan bergerak, melindungi satuan sendiri dan menghindari jatuhnya informasi ke tangan lawan. Asas keamanan diterapkan mulai proses perencanaan, pelaksanaan sampai dengan pengakhiran operasi dengan tujuan untuk menghindari kegagalan dalam pelaksanaan OMSP.

e. Asas Legitimasi di artikan bahwa pelaksanaan OMSP yang dilaksanakan oleh TNI sudah berdasar kepada peraturan perundangan yang berlaku dan keputusan politik Negara.

f. Asas keterpaduan Mengingat OMSP merupakan operasi yang melibatkan institusi di luar TNI, maka diperlukan adanya persamaan persepsi, koordinasi yang tepat dan keterpaduan dalam kesatuan dan dukungan.

g. Asas ekonomis

Dalam OMSP harus di pertimbangkan penggunaan kekuatan secara ekonomis.Segala factor harus diperhitungkan dengan cermat, sehingga pada pelaksanaannya dapat dikerahkan kekuatan secara efektif dan efisien. ${ }^{21}$

Keterlibatan pihak militer dalam penanggulangan gerakan separatisme atau pemberontakan juga diatur dalam $\begin{array}{llll}\text { penjelasan } & \text { Pasal } 7 & \text { Undang-Undang }\end{array}$

\footnotetext{
${ }^{21}$ Markas Besar Tentara Nasional Indonesia, OMP-OMSP, Babinkum TNI, 2011, hlm. 85
}

Volume 3 Nomor 1, Desember 2017 | 26 
Nomor 3 Tahun 2002 yang mengkategorikan pemberontakan bersenjata sebagai ancaman militer. Yang dimaksud dengan ancaman militer itu sendiri adalah ancaman yang menggunakan kekuatan bersenjata yang terorganisasi yang dinilai mempunyai kemampuan yang membahayakan kedaulatan negara, keutuhan wilayah negara, dan keselamatan segenap bangsa.

Lebih lanjut, amanat Undang-Undang Nomor 3 Tahun 2002 dan Undang-Undang Nomor 34 Tahun 2004 mengenai menanggulangi gerakan separatisme dirumuskan dalam Peraturan menteri Pertahanan Republik Indonesia Nomor 5 tahun 2011 tentang Kebijakan Pertahanan Negara Tentang Tugas Tentara Nasional Indonesia Dalam Mengatasi Gerakan Separatisme, yang kemudian digunakan sebagai pedoman dan dilaksanakan dalam mengatasi Separatisme.

\subsection{PENANGGULANGAN SEPARATISME DI INDONESIA DALAM KACAMATA HUKUM HUMANITER INTERNASIONAL}

Mengenai hubungan sistem hukum internasional dengan sistem hukum nasional dikenal paham atau teori dualisme dan monisme.Menurut paham atau teori dualisme, hukum internasional dan hukum nasional merupakan dua sistem hukum yang berbeda secara intrinsik.Hukum internasional bersumber pada kehendak bersama atau kesepakatan negara-negara sementara hukum nasional bersumber pada kehendak negara dan kekuasaan negara.Hukum internasional dilandasi prinsip dasar pacta sunt servanda, sedangkan hukum nasional dilandasi prinsip dasar bahwa peraturan perundangundangan harus ditaati.Namun hukum internasional dan hukum nasonal keduanya bertujuan menciptakan ketertiban dan keadilan. ${ }^{22}$

Sedangkan paham monisme menganggap bahwa hukum internasioanl

\footnotetext{
22 Penerapan Konvensi Jenewa 1949 dan Protokol

Tambahan dalam Hukum Nasional Indonesia (Studi tentang Urgensi dan Prosedur Ratifikasi Protokol Tambahan 1977), Isplancius Ismail, Fakultas Hukum Universitas Jenderal Soedirman, Jurnal Dinamika Hukum, Vol. 13 No 3 September 2013, Hal. 368
}

dan hukum nasional merupakan satu sistem hukum pada umumnya.Semua ketentuan hukum merupakan kesatuan sistem yang terdiri dari ketentuan hukum yang mengikat negara, individu maupun kesatuan bukan negara.Hukum nasional dan hukum internasional secara keseluruhan merupakan dari sistem hukum universal yang mengikat manusia baik secara individual maupun secara kolektif. Hukum internasional mengikat individu secara kolektif sedang hukum nasional mengikat individu secara perorangan

Berlakunya ketentuan-ketentuan hukum internasional ke dalam hukum nasional dilakukan dengan berlandaskan pada teori-teori transformasi dan delegasi.Adapun dalam praktik negara dikenal beberapa istilah untuk realisasi penerapan hukum internasional ke dalam hukum nasional seperti ratifikasi (ratification) dan aksesi (accession). ${ }^{23}$

Indonesia telah meratifikasi seluruh Konvensi Jenewa 1949 dengan adanya Undang-Undang Nomor 59 Tahun 1958 tentang Ikut Serta Negara Republik Indonesia Dalam Seluruh Konvensi Jenewa Tanggal 12 Agustus 1949. Pasal 27 Konvensi Jenewa keempat tahun 1949 menyatakan bahwa Hukum Den Haag dan Hukum Jenewa merupakan sumber pokok Hukum Humaniter Internasional sehingga Indonesia juga harus mematuhi dan mentaati Hukum Den Haag.

Namun mengenai Protokol Tambahan I (mengatur ketentuan-ketentuan tentang konflik bersenjata yang bersifat internasional) dan II (mengatur ketentuanketentuan tentang konflik bersenjata yang bersifat non internasional) Tahun 1977 hingga saat ini Indonesia belum meratifikasi kedua Protokol Tambahan 1977 tersebut. Protokol Tambahan I belum diratifikasi karena Indonesia masih merasa keberatan mengenai apa yang dimaksud dengan bangsa yang tertera dalam pasal 1 ayat (4) juncto pasal 96 ayat (3). Protokol Tambahan II belum diratifikasi karena masih adanya kekhawatiran bahwa Protokol Tambahan Ilini akan dijadikan alat bagi pemberontak untuk melakukan tuntutan internasional. Sejalan dengan ini, tidak dapat dipungkiri bahwa Indonesia

\footnotetext{
23 Ibid. Hal 369
}

Volume 3 Nomor 1, Desember 2017 | 27 
telah meratifikasi Konvensi Jenewa 1949 tanpa syarat. Oleh karena itu sudah seharusnya dan selayaknya Indonesia menghormati konvensi tersebut. ${ }^{24}$

\subsection{PENEGAKAN HAM DALAM PENENGGULANGAN GERAKAN SEPARATIS OLEH MILITER}

Meski telah diamanatkan oleh Hukum Nasional bahwa militer dalam hal ini Tentara Republik Indonesia untuk menanggulangi segala bentuk gerakan separatis yang merongrong kedaulatan Bangsa Indonesia, sudah seharusnya setiap Operasi Militer Selain Perang tetap menjunjung tinggi Hak Asasi Manusia. Pasca Reformasi, Indonesia mengamandemen konstitusi sebagai itikad menjunjung tinggi Hak Asasi Manusia dan mencegah pelanggaran hak tersebut seperti yang terjadi di masa aman Orde Baru yang kemudian dikeluarkannya Undang-Undang Nomor 39 Tahun 1999 tentang Hak Asasi Manusia. Sejalan dengan ini, sebelum lahirnya UndangUndang Hak Asasi Manusia di Indonesia, peraturan mengenai HAM telah diatur dalam Konvensi Jenewa 1949 yaitu Konvensi Jenewa Mengenai Perlindungan Orang Sipil di waktu Perang dan Konvensi Jenewa mengenai Perlakuan Tawanan Perang.

Atas dasar inilah, maka Operasi Militer Selain Perang yang dilakukan oleh TNI untuk menanggulangi separatisme di Indonesia sudah seharusnya memperhatikan Hak Asasi Manusia, sebagaimana telah diatur dalam Hukum Humaniter Internasional. Ini disebabkan Indonesia telah meratifikasi Konvensi Jenewa 1949 dan merupakan konsekuensi yuridis untuk setiap Negara yang menandatangani konvensi tersebut untuk mematuhinya. Pasal 3 Konvensi Jenewa 1949 menegaskan bahwa dalam hal terjadi pertikaian bersenjata yang tidak bersifat internasional yang berlangsung dalam wilayah salah satu Negara yang mendatangani Konvensi Jenewa, tiap pihak yang bertikai harus memperhatikan aturanaturan tentang kemanusiaan, antara lain larangan:

a. tindakan kekerasan atas jiwa dan raga;

\footnotetext{
24 Ibid. Hal 372
}

b. penyanderaan;

c. perkosaan atas kehormatan pribadi

d. menghukum dan menjalankan hukuman mati tanpa didahului keputusan yang dijatuhkan oleh suatu pengadilan yang dibentuk secara teratur.

Sementara itu Pasca 1998 , TNI mulai memberlakukan pendidikan Hak Asasi Manusia dan dibekali dengan Buku Saku "Pedoman Prajurit Dalam Penerapan Hak Asasi Manusia" untuk mengetahui batasbatas wewenang yang ditetapkan dalam perundangan yang berlaku. ${ }^{25} \mathrm{Di}$ dalam buku pedoman tersebut secara jelas tertulis bahwa setiap prajurit TNI dilarang:

1. Melakukan pembunuhan dan penyiksaan, jikapun terpaksa pembunuhan hanya boleh dilakukan terhadap musuh bersenjata dalam pertempuran;

a. Bila lawan menyerah atau tertangkap mereka berhak memperoleh perlindungan dan diperlakukan sesuai hukum yang berlaku. Mereka tidak boleh disiksa atau dibunuh.

b. Perkosaan terhadap wanita bertentangan dengan kode kehormatan militer dan tindakan tersebut melanggar Hak Asasi Manusia.

c. Menggunakan teknik penyiksaan untuk memperoleh pengakuan/ keterangan. Keterangan yang didapat melalui penyiksaan membuat keterangan tersebut diragukan dan tidak dapat digunakan untuk menempatkan seseorang menjadi tersangka.

d. Kepentingan militer, keamanan nasional dan dasar-dasar lainnya bukanlah pembenaran untuk penyiksaan;

e. Perlakukan yang salah terhadap rakyat akan merugikan pelaksanaan tugas dan membuka kesempatan untuk mendiskreditkan institusi TNI.

\footnotetext{
${ }^{25}$ Pusat Penerangan TNI, "Prajurit TNI dalam Penerpaan Hak Asasi Manusia (HAM),"tni.mil.id/view-25111-prajurit-tnidalam-penerapan-hak-asasi-manusia-ham.html diakses pada 4 Oktober 2017
}

Volume 3 Nomor 1, Desember 2017 | 28 
2. Menculik/Menghilangkan

orang dengan paksa;

a. Setiap anggota TNI dilarang untuk menangkap dan/atau menahan seseorang di luar ketentuan hukum yang berlaku.

b. Orang yang ditangkap/ditahan oleh TNI berada dalam penguasaan sesuai dengan kewenangan peraturan perundangan dan menjadi tanggung jawab komandan satuan sebagai pejabat negara.

c. Penangkapan dan/atau penahanan harus diikuti tindakan:

- Pencatatan identitas, alasan penangkapan dan/atau penahanan, hari-tanggalwaktutempat penahanan dan pelepasan, termasuk pencatatan pemindahan tempat penahanan bila terjadi pemindahan;

- Pelaporan kepada komando atas;

- Penginformasian kepada keluarga orang yang ditangkap/ditahan;

- Pemberian kesempatan untuk berhubungan dengan keluarga baik kunjungan maupun melalui surat

3. Merusak dan mengambil harta benda orang lain;

a. Setiap prajurit harus menghindarkan diri dari tindakan perusakan harta benda orang lain yang dapat menimbulkan penderitaan rakyat.

b. Pengambilan/pencurian harta benda rakyat merugikan dan menyakiti hati rakyat dan menambah kesulitan mereka

4. Menghukum diluar keputusan pengadilan atau main hakim sendiri.

a. Setiap prajurit harus menyadari bahwa hak hidup, hak kebebasan dan hak atas harta benda seseorang di negara hukum Indonesia tidak dapat dicabut kecuali melalui putusan peradilan;

b. Penghukuman seseorang dapat dilakukan setelah proses peradilan dan penjatuhan putusan; c. Setiap orang tanpa diskriminasi agama, suku, ras, etnik, kelompok, golongan, status sosial dan ekonomi, jenis kelamin, bahasa dan keyakinan politik sama di hadapan hukum

Dalam Buku Saku Pedoman Hak Asasi Manusia untuk Angkatan Darat (AD) itu pun tertulis bahwa "Sejuta musuh yang berhasil kau bunuh dalam pertempuran kau adalah pahlawan. Tetapi satu orang rakyat terluka karena tindak kekerasan, sejuta musuh yang kau bunuh tidak membebaskan dirimu dari jerat hukum atas pelanggaran Hak Asasi Manusia yang kau lakukan". 26

Selain itu TNI mendapat pengenalan mengenai defnisi kesewenangan (abuse of power), kelalaian dalam melaksanakan tugas (violence by omission) dan pelanggaran Hak Asasi Manusia berat (gross violation of human rights). Meski sudah cukup maju dalam aturan hukum negara dan institusi militer, kemajuan penghormatan atas Hak Asasi Manusia ini tetap memiliki celah karena prajurit TNI, seperti layaknya warga negara lainnya, berhak menggunakan Pasal 49 KUHP untuk dirinya. Pasal ini menyatakan bahwa setiap orang yang melakukan kekerasan terhadap orang lain tidak akan mendapat hukuman jika tindakan tersebut ditujukan untuk melindungi nyawa, badan dan/atau harta benda orang lain.

Oleh sebab itu maka TNI masih memiliki sistem peradilan tersendiri, yakni peradilan militer. Atas dasar inilah maka setiap pelanggaran yang dilakukan oleh pihak militer sudah seyogyanya menjadi pertimbangan hakim dalam mengambil setiap keputusan. Hal ini dikarenakan penyimpangan atau pelanggaran yang dilakukan oleh salah satu anggota TNI dalam Operasi Militer Selain Perang bisa jadi lebih mementingkan perlindungan terhadap keutuhan NKRI. ${ }^{27}$

\footnotetext{
${ }^{26}$ Buku Saku Pedoman Prajurit TNI AD Dalam Penerapan Hak Asasi Manusia (HAM) https://www.scribd.com/doc/59321708/Buku-Saku-PrajuritTni-Ad-Ttg-Ham, diakses pada 4 Oktober 2017

${ }^{27}$ Almanak Hak Asasi Manusia di Sektor Keamanan Indonesia 2014, Institute for Defence Security and Peace Studies, DCAF a centre for security, development and the rule of la, Fitriani, 2015
}

Volume 3 Nomor 1, Desember 2017 | 29 


\section{PENUTUP}

Gerakan separatisme hingga saat ini masih menjadi ancaman nyata bagi persatuan dan kesatuan bangsa. Embrio dari gerakan ini muncul dikarenakan ketidakpuasan elemen masyarakat di daerah terhadap kebijakan Pemerintah yang dinilai tidak adil. Oleh karena itu berdasarkan amanat Undang-Undang Nomor 34 Tahun 2004 tentang Tentara Nasional Indonesia, maka salah satu tugas TNI selain Operasi Militer untuk Perang (OMP) yakni mengatasi gerakan separatisme berdasakan tugas pokok TNI OMSP (Operasi Militer Selain Perang).

Menggunakan kekuatan pertahanan militer dalam) menghadapi ancaman separatisme dan pemberontakan bersenjata dilakukan berdasarkan putusan politik pemerintah dan dilindungi oleh undang-undang. Penggunaan kekuatan TNI melalui OMSP ini dengan mengembangkan strategi operasi yangtepat dan efektif sesuai dengan situasi dan kondisi yang dihadapi.

OMSP yang dilakukan oleh pihak militer tidak lain meruupakan fungsi TNI sebagai alat pertahanan mnegara yaitu menangkap setidap bentuk ancaman militer dan ancaman bersenjata dari luar dan dalam negeri terhadap kedaulatan, keutuhan wilayah, dan keselamatan bangsa. Hal ini sejalan dengan dalam $B A B$ III Doktrin Tentara Nasional Indoensia Tridarma Ekakarma (TRIDEK) Tugas Pokok TNI adalah menegakkan kedaulatan negara, mempertahankan keutuhan wilayah Negara Kesatuan Republik Indonesia (NKRI) yang berdasarkan Pancasila dan UUD NKRI Tahun 1945, serta melindungi segenap bangsa dan seluruh tumpah darah Indonesia dari ancaman dan gangguan terhadap keutuhan bangsa dan negara.

Akan tetapi, dalam melaksanakan mencegah dan menanggulangi separatisme, pihak militer sudah seyogyanya untuk memperhatikan Hukum Humaniterlnternasional. Hukum Humaniter yang terdiri dari Hukum DenHaag dan Hukum Jenewa, pada prinsipnya melindungi hak perorangan disaat terjadi konflik bersenjata. Segala bentuk pelaksanaan penyelenggaraan pertahanan negara baik berupa OMP ataupun OMSP,
TNI harus senantiasa berpedoman pada Hukum Humaniter, hukum kebiasaan internasional dan Hukum Hak Azasi Manusia Nasional suatu hukum internasional universal, hal ini sesuai dengan Keputusan Menteri Pertahanan Nomor : Kep/02/M/l//2002 tentang Penerapan Hukum Humaniter dan Hukum Hak Azasi Manusia dalam penyelenggaraan Pertahanan Negara.

Ini dikarenakan, isu HAM menjadi hal yang cukup menonjol ketika Negara beserta aparatnya melaksanakan kewajiban-kewajibannya seperti penanggulangan gerakan separatisme, sedangkan penanggulangan ancaman terhadap kedaulatan, integritas dan keselamatan Negara merupakan tugas dan tanggung jawab TNI. Oleh karena itu, untuk menjamin kepastian hukum dan kredibilitas tindakan penanggulangan ancaman tersebut, maka perlu adanya pemahaman yang baik dari setiap prajurit mengenai penerapan Hukum Humaniter dan HAM. Setiap prajurit dan satuan TNI berkewajiban untuk mematuhi Hukum Humaniter dan HAM tersebut dalam melaksanakan tugas yang dibebankan baik dalam kerangka Operasi Militer Perang maupun Operasi Militer Selain Perang. Setiap Prajurit wajib memahami dan mampu melaksanakan kewajibankewajibannya sesuai dengan hukum dan kebiasaan perang yang terdapat dalam berbagai konvensi internasional yang berlaku dan mengikat terhadap Negara Indonesia.

\section{DAFTAR PUSTAKA}

Buku Putih Pertahanan Indonesia 2014, Departemen Pertahanan Republik Indonesia.

\section{Buku Saku Pedoman Prajurit TNI AD Dalam Penerapan Hak Asasi Manusia (HAM) https://www.scribd.com/doc/5932170 8/Buku-Saku-Prajurit-Tni-Ad-Ttg-Ham download 3 Oktober 2017.}

Fitriani, Almanak Hak Asasi Manusia di Sektor Keamanan Indonesia 2014,

Volume 3 Nomor 1, Desember 2017 | 30 
Institute for Defence Security and Peace Studies, DCAF a centre for security, development and the rule of law, 2015.

Hamid, Abdul, Gerakan Separatisme ditinjau dari Hukum Humaniter Internasional, Fakultas Hukum Universitas Sumatera Utara, 2001.

Hiariej, Eddy O.S, Pengantar Hukum Pidana Internasional, Erlangga, 2009.

Hukum Pidana Internasional dan Perempuan, Buku I, Sebuah Acuan Untuk Praktisi, Publikasi Komnas Perempuan.

Ismail, Isplancius, Penerapan Konvensi Jenewa 1949 dan Protokol Tambahan dalam Hukum Nasional Indonesia (Studi tentang Urgensi dan Prosedur Ratifikasi Protokol Tambahan 1977), Fakultas Hukum Universitas Jenderal Soedirman, Jurnal Dinamika Hukum, Vol. 13 No 3 September 2013.

Markas Besar Tentara Nasional Indonesia, OMP-OMSP, Babinkum TNI, 2011.

Mengko, Diandra Megaputri, Jurnal Keamanan Nasional, Pusat Kajian Keamanan Nasional, Universitas Bhayangkara Jakarta Raya, Volume I No. 2015.

Mullinen, de Frederic, Handbook on the Law of the War for Armed Forces, ICRC, Geneva, 1987.

Peraturan menteri Pertahanan Republik Indonesia Nomor 5 tahun 2011 tentang Kebijakan Pertahanan Negara Tentang Tugas Tentara Nasional Indonesia Dalam Mengatasi Gerakan Separatisme.
Pusat Penerangan TNI, "Prajurit TNI dalam Penerapan Hak Asasi Manusia (HAM)," dalam tni.mil.id/view-25111prajurit-tni-dalam-penerapan-hakasasi-manusia-ham.html diakses pada 4 Oktober 2017.

Siswanto, Arie, Hukum Pidana Internasional, Andi, Yogyakarta, 2015.

TAP MPR No. VII.2000 tentang Peran Tentara Nasional Indonesia dan Kepolisian Negara Republik Indonesia.

Undang-Undang Nomor 3 Tahun 2002 tentang Pertahanan Negara.

Undang-Undang Nomor 34 Tahun 2004 tentang Tentara Nasional Republik Indonesia. 